\title{
Prevalence of Pseudomonas aeruginosa and Acinetobacter spp. in subgingival biofilm and saliva of subjects with chronic periodontal infection
}

\author{
Renata Souto $^{1}$, Carina M. Silva-Boghossian ${ }^{2}$, Ana Paula Vieira Colombo ${ }^{1}$ \\ ${ }^{1}$ Instituto de Microbiologia, Universidade Federal do Rio de Janeiro, Rio de Janeiro, RJ, Brazil. \\ ${ }^{2}$ Departamento de Clínica Odontológica, Faculdade de Odontologia, Universidade Federal \\ do Rio de Janeiro, Rio de Janeiro, RJ, Brazil.
}

Submitted: August 27, 2012; Approved: September 9, 2013.

\begin{abstract}
P. aeruginosa and Acinetobacter spp. are important pathogens associated with late nosocomial pneumonia in hospitalized and institutionalized individuals. The oral cavity may be a major source of these respiratory pathogens, particularly in the presence of poor oral hygiene and periodontal infection. This study investigated the prevalence of $P$. aeruginos $a$ and Acinetobacter spp. in subgingival biofilm and saliva of subjects with periodontal disease or health. Samples were obtained from 55 periodontally healthy $(\mathrm{PH})$ and 169 chronic periodontitis $(\mathrm{CP})$ patients. DNA was obtained from the samples and detection of $P$. aeruginosa and Acinetobacter spp. was carried out by multiplex and nested PCR. P. aeruginosa and Acinetobacter spp. were detected in $40 \%$ and $45 \%$ of all samples, respectively. No significant differences in the distribution of these microorganisms between men and women, subgingival biofilm and saliva samples, patients $\leq 35$ and $>35$ years of age, and smokers and non-smokers were observed regardless periodontal status $(\mathrm{p}>0.05)$. In contrast, the frequencies of $P$. aeruginosa and Acinetobacter spp. in saliva and biofilm samples were significantly greater in $\mathrm{CP}$ than PH patients $(\mathrm{p}<0.01)$. Smokers presenting $P$. aeruginos $a$ and high frequencies of supragingival plaque were more likely to present CP than PH. P. aeruginosa and Acinetobacter spp. are frequently detected in the oral microbiota of CP. Poor oral hygiene, smoking and the presence of $P$. aeruginosa are strongly associated with periodontitis.
\end{abstract}

Key words: Pseudomonas aeruginosa, Acinetobacter spp., subgingival biofilm, saliva, periodontitis, PCR.

\section{Introduction}

Periodontal diseases are bacterial infections associated with a complex microbiota of the dental biofilm that induces a local and systemic inflammatory response, leading to periodontal tissue destruction (Page and Kornam, 1997; Paster et al., 2006; Socransky et al., 1998). The microbial diversity of the human oral cavity has been recognized for decades, and over 700 species have been identified in this habitat (Paster et al., 2006). In addition to the resident oral species, studies have shown that the oral cavity harbours high proportions of various medically important pathogens, particularly in individuals with poor oral hygiene, periodontal diseases and/or immunosuppression
(Ali et al., 1994, 1996; Botero et al., 2007; Colombo et al., 2002, 2009; Da Silva-Boghossian et al., 2011; Fritschi et al., 2008; Gonçalves et al., 2009; Persson et al., 2008; Slots et al., 1988, 1990; Souto and Colombo 2008; Souto et al., 2006). Conceivably, these species may disseminate to distant body sites increasing the risk for systemic infectious conditions such as bacterial pneumonia (Paju and Scannapieco, 2007; Scannapieco, 1998; Scannapieco et al., 1998).

Pseudomonas aeruginosa and Acinetobacter spp. are major respiratory pathogens associated with late-onset nosocomial pneumonia in hospitalized and institutionalized individuals (Chastre and Fagon, 2002). P. aeruginosa can be identified in a range of infections, especially those with a tendency to become chronic such as lung infections 
in cystic fibrosis patients (Wagner and Iglewski, 2008). This species presents many virulence properties including the ability to produce and secrete extracellular enzymes and toxins (Pihl et al., 2010; Smith and Iglewski, 2003, Woods et al., 1982) to adhere to and form biofilms on tissues and abiotic surfaces (Pihl et al., 2010; Smith and Iglewski, 2003), as well as to present resistance to many antibiotics (Slots et al., 1988, 1990). Acinetobacter spp. are a major concern in nosocomial infections due to their rapid development of multi-drug resistance, surviving desiccation and persistence in the environment for long periods of time (Fourrier et al., 1998; Karlowsky et al., 2003; Luna et al., 2007). These organisms are associated with bacteremia, pulmonary infections, meningitis, diarrhea and notorious nosocomial infections with mortality rates of 20 to $60 \%$ (Luna et al., 2007). Transmission is via person-to-person contact, contaminated water, food and hospital equipment (Agodi et al., 2007; Luna et al., 2007). The prevalence of Pseudomonas and Acinetobacter spp. in subjects with periodontal diseases may vary widely among different populations (Ali et al., 1994, 1996; Colombo et al., 2002; Persson et al., 2008; Slots et al., 1988, 1990; Slots et al., 1991; Souto et al., 2006). These pathogens have also been associated with treatment failure in patients with refractory periodontitis (Colombo et al., 1998, 2009). The role of these microorganisms in the etiology and pathogenesis of periodontal diseases is unclear. Regardless, we hypothesized that the existence of disease may increase colonization of the oral microbiota by these species. The aim of this study was to determine the carriage rate of $P$. aeruginosa and Acinetobacter spp. in the subgingival biofilm and saliva of subjects with periodontal health or chronic periodontitis.

\section{Methods}

\section{Subject population and clinical diagnosis}

Two hundred and twenty four adult subjects who sought dental treatment at the Dental School of the Federal University of Rio de Janeiro, Brazil were recruited for the study. Informed consent was obtained from all enrolled individuals. The study protocol was approved by the Review Committee for Human Subjects of the Clementino Fraga Filho University Hospital. Exclusion criteria included pregnancy, use of local or systemic antimicrobial agents within 6 months prior to the entry into the study, diabetes and other systemic conditions that could affect the periodontal status. All subjects had at least 10 natural teeth and were over 18 years of age. During the first visit, subjects were submitted to an anamnesis questionnaire, and information regarding age, gender and smoking status was obtained. Smoking was recorded as never-having-smoked and smoker (current or former smokers). Periodontal clinical measurements were performed at six sites per tooth and included probing depth (PD), clinical attachment level
(CAL), presence or absence of supragingival biofilm (SB), bleeding on probing (BOP) and suppuration (SUP). After initial clinical evaluation, subjects were categorized as periodontally healthy $(\mathrm{PH}, \mathrm{n}=55)$ or chronic periodontitis $(\mathrm{CP}, \mathrm{n}=169)$. The PH controls had no sites with PD and/or $\mathrm{CAL}>3 \mathrm{~mm}$ and no more than $10 \%$ of sites with BOP. CP patients presented at least $10 \%$ of teeth with $\mathrm{PD}$ and/or CAL $35 \mathrm{~mm}$, or at least $15 \%$ of teeth with PD and /or CAL $34 \mathrm{~mm}$, and $>10 \%$ of sites with BOP. After clinical examination and sampling, subjects with evidence of destructive periodontal disease were treated for periodontitis by full mouth scaling and root planning under local anesthetic and instructions in proper home care procedures in the Department of Dental Clinic at the Federal University of Rio de Janeiro.

\section{Sampling}

After removal of supragingival biofilm with sterile gauze, subgingival biofilm samples were taken of up to 6 sites with $\mathrm{PD} \geq 4 \mathrm{~mm}$ and BOP from $\mathrm{CP}$ patients, and from 3 randomly selected sites with $\mathrm{PD}<4 \mathrm{~mm}$ and no $\mathrm{BOP}$ from $\mathrm{PH}$ individuals using sterile periodontal curettes (Hu-Friedy, Chicago, IL). For each patient, samples were pooled and placed in Eppendorf tubes containing $500 \mu \mathrm{L}$ of TE (Tris-HCl $10 \mathrm{mM}$, EDTA $1 \mathrm{mM}$, pH 7.6). For saliva samples, patients were not allowed to clean their teeth or to eat $30 \mathrm{~min}$ before sampling. They rinsed out their mouths with $10 \mathrm{~mL}$ of $0.9 \%$ sterile saline for $60 \mathrm{~s}$, and the mouthwashes were collected in sterile plastic recipients. All samples were stored in a freezer at $-20^{\circ} \mathrm{C}$.

\section{Isolation of bacterial DNA}

Bacterial DNA was extracted from saliva and subgingival biofilm samples according to the methodology described by Laine et al. (2000). Briefly, samples were centrifuged at $300 \mathrm{xg}$ for $10 \mathrm{~min}$. The pellet was washed twice in $0.9 \%$ saline, re-suspended in $100 \mu \mathrm{L}$ of $50 \mathrm{mM} \mathrm{NaOH}$ and boiled for $10 \mathrm{~min}$. Samples were then neutralized with $14 \mu \mathrm{L}$ of $1 \mathrm{M}$ Tris ( $\mathrm{pH} 7.5$ ) and centrifuged at $14,000 \mathrm{x} g$ for 3 min. Supernatants were collected and stored at $-20^{\circ} \mathrm{C}$ until PCR amplification was performed.

\section{Detection of $P$. aeruginosa and Acinetobacter spp. by multiplex and nested PCR}

For PCR detection of P. aeruginosa, two sets of primers were used: one set (PS1, 5'-ATGAACAACGTTCTGAAATTCTCTGCT-3' and PS2, 5'-CTTGCGGCTGGCTTTTTCCAG-3') consisted of primers corresponding to the beginning and the end of the open reading frame of the OprI gene (De Vos et al., 1997), while the other set of primers (PAL1, 5'-ATGGAAATGCTGAAATTCGGC-3' and PAL2, 5'-CTTCTTCAGCTCGACGCGGACG-3') corresponded to the open reading frame of the OprL gene. A negative 
control with no DNA template and a positive control consisting of $20 \mu \mathrm{L}$ of DNA obtained from the $P$. aeruginosa strain ATCC 27853 were used in all reactions. The PCR reaction was performed in a $100 \mu \mathrm{L}$ reaction mixture containing 30 pmol of each primer, $10 \mu \mathrm{L}$ of $10 \mathrm{X}$ PCR buffer, $1.5 \mathrm{mM}$ of $\mathrm{MgCl}_{2}, \quad 0.2 \mathrm{mM}$ of desoxynucleotide triphosphate mixture (final concentration $0.2 \mathrm{mM}$ each dATP, dCTP, dTTP and dGTP), 2 U of Platinum ${ }^{\circledR}$ Taq DNA polymerase (Invitrogen, Grand Island, NY) and $20 \mu \mathrm{L}$ of DNA template. The reaction was performed in a thermal cycler Primus 25/96, MWG (Biotech, Ebersberg, Germany). The initial denaturation step occurred at $95{ }^{\circ} \mathrm{C}$ for $2 \mathrm{~min}$, and was followed by 30 cycles of denaturation at $94{ }^{\circ} \mathrm{C}$ for $40 \mathrm{~s}$, annealing at $57{ }^{\circ} \mathrm{C}$ for $1 \mathrm{~min}$, extension at $72{ }^{\circ} \mathrm{C}$ for $1 \mathrm{~min}$, and a final extension at $72{ }^{\circ} \mathrm{C}$ for $2 \mathrm{~min}$. The products obtained were analyzed on a $1.5 \%$ agarose gel electrophoresis performed at $4 \mathrm{~V} / \mathrm{cm}$ in Tris-acetate-EDTA buffer (TAE). The gel was stained with $0.5 \mu \mathrm{g} / \mathrm{mL}$ ethidium bromide and visualized on an ultraviolet transilluminator (Bioamerica, Miami, USA) A 100 bp ladder digest (Invitrogen) was used as a standard molecular weight. The expected products after amplification were $250 \mathrm{bp}$ and $510 \mathrm{bp}$ in length. A pair of ubiquitous bacterial primers (5'-AGA GTT TGA TCC TGG CTC AG-3' and 5'-ACG GCT ACC TTG TTA CGA CTT- 3') designed by Willis et al. (1999) was used to indicate the presence of bacterial DNA in the clinical samples, particularly the ones that were $P$. aeruginosa-negative. For the reaction using the universal 16S rDNA primers, PCR amplification included a $25 \mu \mathrm{L}$ reaction mixture containing $0.2 \mathrm{mM}$ of forward and reverse universal primers, $2.5 \mu \mathrm{L}$ of 10x PCR buffer, $2 \mathrm{mM} \mathrm{MgCl}_{2}$, 1.25 U of Platinum ${ }^{\circledR}$ Taq DNA polymerase, and $200 \mathrm{mM}$ of each deoxynucleosidetriphosphate (Invitrogen). The PCR program included an initial denaturation step at $97^{\circ} \mathrm{C}$ for $1 \mathrm{~min}$, followed by 30 cycles of a denaturation step at $97{ }^{\circ} \mathrm{C}$ for $45 \mathrm{~s}$, a primer annealing step at $55^{\circ} \mathrm{C}$ for $45 \mathrm{~s}$, an extension step at $72{ }^{\circ} \mathrm{C}$ for $1 \mathrm{~min}$ and a final step of $72{ }^{\circ} \mathrm{C}$ for $4 \mathrm{~min}$. The presence of bacterial DNA was determined by an amplicon of $1,505 \mathrm{bp}$ in size visualized on a $1.5 \%$ agarose gel. Acinetobacter spp. detection was carried out by a nested PCR (Broderick et al., 2004; Vanbroekhoven et $a l ., 2004)$. The first amplification was performed with the bacterial 16S rRNA universal primers 27f, 5'-AGA GTT TGA TCC TGG CTC AG-3' and 1492r, 5'-TAC GGC TAC CTT GTT ACG ACT T-3' (amplicon of 1450 bp). Approximately $100 \mathrm{ng}$ of sample DNA was added into a $50 \mu \mathrm{L}$ PCR mixture containing 0.5 pmol of each primer, $400 \mu \mathrm{M}$ of each dNTP, $3 \mathrm{mM} \mathrm{MgCl}_{2}, 10 \mathrm{x}$ PCR buffer (20 mM Tris- $\mathrm{HCl}$ [pH 8.4], $50 \mathrm{mM} \mathrm{KCl),} \mathrm{and} \mathrm{1.5} \mathrm{U} \mathrm{Plati-}$ num ${ }^{\circledR}$ Taq DNA polymerase (Invitrogen). The amplification program included an initial step of $95{ }^{\circ} \mathrm{C}$ for $5 \mathrm{~min}$ followed by 35 cycles of denaturation at $94{ }^{\circ} \mathrm{C}$ for $30 \mathrm{~s}$, $55^{\circ} \mathrm{C}$ for $1 \mathrm{~min}, 72^{\circ} \mathrm{C}$ for $1 \mathrm{~min}$, and a final step of $72{ }^{\circ} \mathrm{C}$ for $5 \mathrm{~min}$ [34]. The second amplification was performed with the primers Ac436f, 5'-TTT AAG CGA GGA GGA GG-3' and Ac676r, 5'-ATT CTA CCA TCC TCT CCC-3' (amplicon of $280 \mathrm{bp}$ ) in a reaction volume of $50 \mu \mathrm{L}$ containing 2 pmol of primer Ac436f, 1 pmol of primer Ac676r, $200 \mu \mathrm{M}$ of each dNTP, $2 \mathrm{mM} \mathrm{MgCl} 2,10 \mathrm{x}$ PCR buffer, and 1.5 U Platinum ${ }^{\circledR}$ Taq DNA polymerase (Invitrogen). The amplification programme was carried out according to Vanbroekhoven et al. (2004).

\section{Statistical analysis}

All statistical tests were performed using the Statistical Package for the Social Sciences (SPSS Inc ${ }^{\circledR}$.v.10 Chicago, IL, version 17). Full-mouth clinical measurements were computed for each subject and then average across subjects within the groups. Differences on clinical parameters between groups were sought using Mann-Whitney and $\chi^{2}$ tests. The frequency of detection of P. aeruginosa and Acinetobacter spp. were computed for each subject, and significant differences between groups were sought using the $\chi^{2}$ test. Associations between demographic and periodontal parameters, and the frequency of $P$. aeruginos $a$ and Acinetobacter spp. were examined by the $\chi^{2}$ test. Predictor variables for periodontitis were investigated using multivariate logistic regression analysis, from which ORs with $95 \%$ CI were reported. Statistical significance was reached at the $5 \%$ level.

\section{Results}

The demographic and periodontal clinical features of the subject groups are shown in Table 1. CP patients comprised of a significantly higher proportion of smokers ( $\mathrm{p}<0.01$, Chi-square test) and older individuals $(\mathrm{p}<0.01$; Mann-Whitney test) than PH subjects. No significant differences between groups were observed for gender. As ex-

Table 1 - Demographic and full-mouth clinical parameters (mean \pm SD) of Periodontally Healthy $(\mathrm{PH})$ and Chronic Periodontitis (CP) subjects of the study population.

\begin{tabular}{lcc}
\hline Clinical parameters & PH $(\mathrm{N}=55)$ & $\mathrm{CP}(\mathrm{N}=169)$ \\
\hline \%) Males & 31 & 35 \\
$(\%)$ Smokers ${ }^{* *}$ & 6 & 25 \\
Age (years) $^{*}$ & $31.1 \pm 11$ & $40.2 \pm 14$ \\
Number of missing teeth $^{*}$ & $0.95 \pm 1.6$ & $5.6 \pm 5.7$ \\
Probing depth (mm) $^{*}$ & $1.9 \pm 0.5$ & $2.9 \pm 1.1$ \\
Clinical attachment level (mm) $^{*}$ & $2.0 \pm 0.6$ & $3.7 \pm 1.5$ \\
\% sites with: $^{*}$ & & \\
Bleeding on probing $^{*}$ & $2.5 \pm 4.7$ & $43 \pm 28$ \\
Supragingival biofilm $^{*}$ & $11.5 \pm 11$ & $45 \pm 30$ \\
Suppuration $^{*}$ & 0 & $2 \pm 7$ \\
\hline
\end{tabular}

${ }^{*}$ Refers to $\mathrm{p}<0.01$, Mann-Whitney test; ${ }^{* *}$ refers to $\mathrm{p}<0.01$, Chi-square test. 
pected, all clinical parameters of periodontal tissue destruction and inflammation (tooth loss, PD, CAL, BOP, SB and SUP) were significantly greater in the CP group compared to controls ( $\mathrm{p}<0.01$; Mann-Whitney test).

Overall, $P$. aeruginosa was detected in $40 \%$ and Acinetobacter spp. in $45 \%$ of all samples. The frequency of $P$. aeruginosa and Acinetobacter spp. in saliva and biofilm samples from both clinical groups are depicted in Figures 1 and 2. In saliva samples, a significant higher prevalence of $P$. aeruginosa and Acinetobacter spp. were observed in CP subjects $(49.7 \%$ and $51 \%$, respectively) compared to $\mathrm{PH}$ controls (14.6\% and $24.4 \%$, respectively) [p $<0.01$; Chisquare test]. Likewise, $P$. aeruginosa and Acinetobacter spp. were detected significantly more often in subgingival

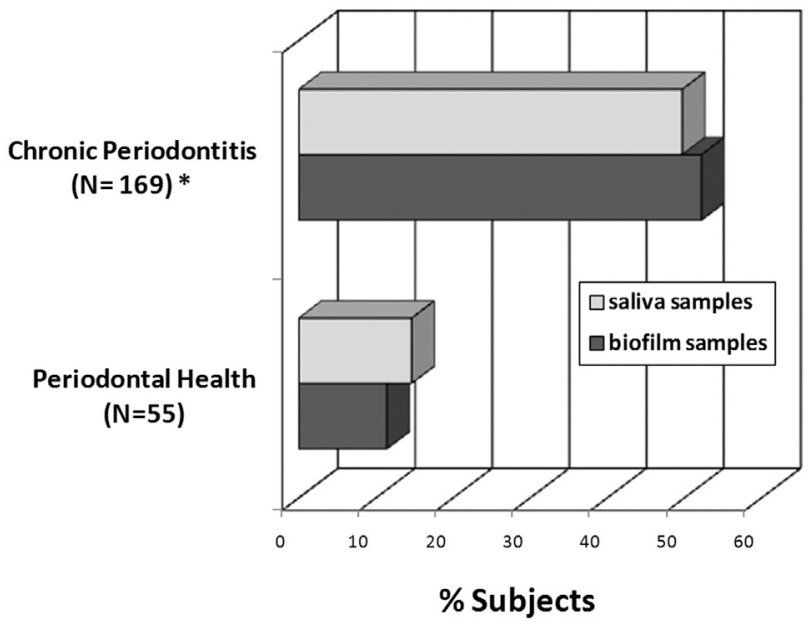

Figure 1 - Frequency of detection of $P$. aeruginosa in saliva and subgingival biofilm samples from periodontally healthy $(\mathrm{N}=55)$ and chronic periodontitis subjects $(\mathrm{N}=169)$. ${ }^{*}$ Significant difference between groups for saliva and biofilm samples $\left(\mathrm{p}<0.05 ; \chi^{2}\right.$ test $)$.

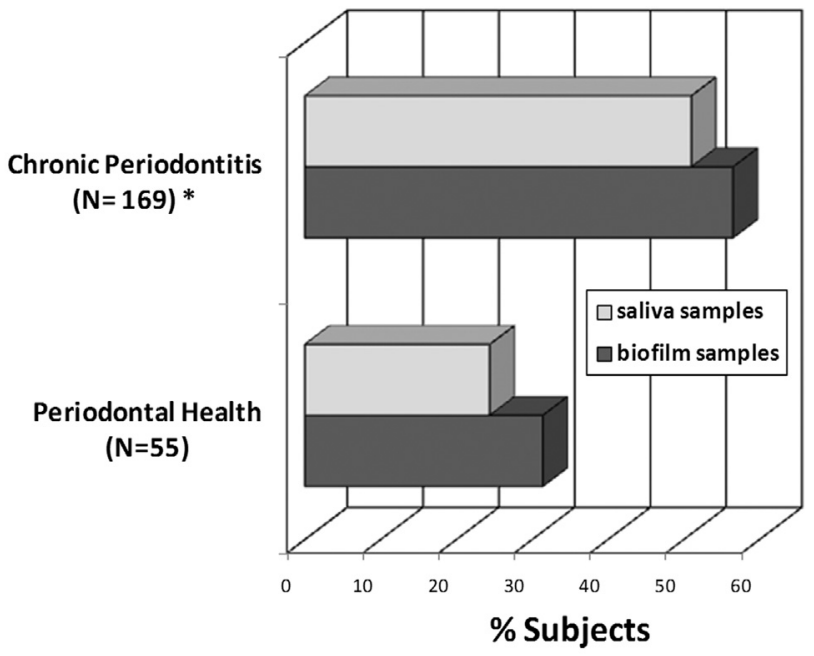

Figure 2 - Frequency of detection of Acinetobacter spp. in saliva and subgingival biofilm samples from periodontally healthy $(\mathrm{N}=55)$ and chronic periodontitis subjects $(\mathrm{N}=169)$. * Significant difference between groups for saliva and biofilm samples $\left(\mathrm{p}<0.05 ; \chi^{2}\right.$ test $)$ biofilm samples from $\mathrm{CP}(52.2 \%$ and $56.5 \%$, respectively $)$ than $\mathrm{PH}$ subjects $(11.4 \%$ and $31.4 \%$, respectively) $[\mathrm{p}<0.01$; Chi-square test]. Due to significant differences in smoking status and age between $\mathrm{CP}$ and $\mathrm{PH}$, the prevalence of $P$. aeruginosa and Acinetobacter spp. were evaluated only in non-smokers and subjects with $\leq 35$ years of age. Both pathogens were more frequently detected in CP than PH subjects ( $p<0.05$; Chi-square test, data not shown). Moreover, there were no significant differences in the distribution of $P$. aeruginosa and Acinetobacter spp. between men and women, subgingival biofilm and saliva samples, patients $\leq 35$ and $>35$ years of age, and smokers and non-smokers regardless periodontal status ( $p>0.05$, Chisquare test, Table 2). Associations between $P$. aeruginosa and Acinetobacter spp. and clinical parameters of disease were also examined (Table 2). For this analysis, only subgingival biofilm samples were considered. Patients with large proportions of visible supragingival biofilm, generalized BOP and periodontal destruction (PD and CAL $>4 \mathrm{~mm}$ ) presented higher frequencies of $P$. aeruginosa and Acinetobacter spp. compared to individuals with less signs of disease ( $p<0.01$, Chi-square test, Table 2). In addition, a strong association between the detection of both species was found. Of the samples positive for $P$. aeruginosa, $76.4 \%$ were also positive for Acinetobacter spp., whereas of the samples negative for $P$. aeruginosa, $75.2 \%$ were negative for Acinetobacter spp. ( $\mathrm{p}<0.001$, Chi-square test, data not shown).

Stepwise logistic regression was performed in order to examine associations between demographic, clinical and bacterial parameters and periodontal status. Table 3 shows the predictor variables entered in the final model to distinguish between periodontal health and chronic periodontitis. Smokers (OR 10.22, CI 2.61-40.0, $\mathrm{p}<0.01$ ) presenting $P$. aeruginosa (OR 7.68, CI 3.13-18.85, $\mathrm{p}<0.001$ ) and high frequencies of supragingival plaque (OR 3.77, CI $1.12-12.62, \mathrm{p}<0.05$ ) were more likely to present chronic periodontitis than periodontal health.

\section{Discussion}

Over the last few years, studies have indicated that the presence of non-oral species in the oral microbiota is not a transitory event or a result of contamination during sampling, and that the oral cavity may be a reservoir for medically important pathogens (Barbosa et al., 2001; Botero et al., 2007; Colombo et al., 2002; Da Silva-Boghossian et al., 2011; Fourrier et al., 1998; Fritschi et al., 2008; Gonçalves et al., 2009; Slots et al., 1988, 1990; Souto and Colombo, 2008; Souto et al., 2006). It is possible that in addition to putative periodontal pathogens, species such as Acinetobacter spp. and P. aeruginosa, either associated with oral pathogens or not, may also play a role in the etiopathogenesis of periodontal diseases. The current investigation examined the subgingival biofilm and saliva 
Table 2 - Association between the frequency (\%) of P. aeruginosa and Acinetobacter spp. and demographic and periodontal clinical parameters in all subjects.

\begin{tabular}{|c|c|c|}
\hline $\begin{array}{l}\text { Demographic and clinical } \\
\text { parameters }\end{array}$ & $\%$ P. aeruginosa & $\%$ Acinetobacter spp. \\
\hline \multicolumn{3}{|l|}{ Gender } \\
\hline males & 37 & 44 \\
\hline females & 42 & 46 \\
\hline \multicolumn{3}{|l|}{ Smoking status } \\
\hline non-smokers & 39 & 43 \\
\hline smokers & 46 & 58 \\
\hline \multicolumn{3}{|l|}{ Age } \\
\hline$\leq 35$ years & 35 & 43 \\
\hline$>35$ years & 44 & 47 \\
\hline \multicolumn{3}{|l|}{ Type of sample } \\
\hline Saliva & 42 & 45 \\
\hline Subgingival biofilm & 35 & 46 \\
\hline \multicolumn{3}{|l|}{ Probing depth * } \\
\hline$\leq 4 \mathrm{~mm}$ & 16 & 28.4 \\
\hline$>4 \mathrm{~mm}$ & 55 & 65 \\
\hline \multicolumn{3}{|l|}{ Clinical attachment level * } \\
\hline$\leq 4 \mathrm{~mm}$ & 16.3 & 29 \\
\hline$>4 \mathrm{~mm}$ & 50 & 57 \\
\hline \multicolumn{3}{|l|}{ Bleeding on probing * } \\
\hline$\leq 30 \%$ of sites & 15 & 29 \\
\hline$>30 \%$ of sites & 54 & 56 \\
\hline \multicolumn{3}{|l|}{ Supragingival biofilm * } \\
\hline$\leq 30 \%$ of sites & 14 & 27 \\
\hline$>30 \%$ of sites & 50 & 56 \\
\hline
\end{tabular}

* Refers to $\mathrm{p}<0.01$, Chi-square test.

from patients with chronic periodontitis and periodontal health for the presence of $P$. aeruginosa and Acinetobacter spp. Data correlating periodontal infection and $P$. aeruginosa or Acinetobacter spp. colonization have indicated that, in general, the prevalence of these species in the oral cavity gets greater proportions in individuals with periodontitis (Barbosa et al., 2001; Botero et al., 2007; Colombo et al., 1998, 2002, 2009; Da Silva-Boghossian et al., 2011; Fourrier et al., 1998; Fritschi et al., 2008; Gonçalves et al., 2009; Persson et al., 2008; Slots et al., 1988, 1990; Souto and Colombo, 2008; Souto et al., 2006). Likewise, our results showed a significantly higher frequency of $P$. aeruginosa and Acinetobacter spp. in saliva and subgingival biofilm samples from periodontitis patients compared to periodontally healthy control. These species have also been associated with treatment failure in patients with refractory periodontitis treated with mechanical and antimicrobial therapy (Colombo et al., 1998, 2009). Conceivably, the high rates of resistance to multiple prescribed broad spectrum antibiotics, as well as the ability to produce
Table 3 - Final model of the stepwise logistic regression analysis including demographic, clinical and bacterial parameters as predictor variables for chronic periodontal disease.

\begin{tabular}{lccccc}
\hline Variables $^{* *}$ & $\beta$ & OR $^{*}$ & $\begin{array}{c}\text { Lower } \\
95 \% \mathrm{CI}\end{array}$ & $\begin{array}{c}\text { Upper } \\
95 \% \mathrm{CI}\end{array}$ & $\mathrm{p}$ \\
\hline Constant & -1.35 & 0.26 & & & $<0.001$ \\
Smoker & 2.32 & 10.22 & 2.61 & 40.0 & $<0.01$ \\
$\begin{array}{l}\text { Pseudomonas } \\
\text { aeruginosa }\end{array}$ & 2.04 & 7.68 & 3.13 & 18.85 & $<0.001$ \\
$\begin{array}{l}\text { Supragingival } \\
\text { biofilm }\end{array}$ & 1.33 & 3.77 & 1.12 & 12.62 & $<0.05$ \\
\hline
\end{tabular}

*Reference: Periodontally healthy; ${ }^{* *}$ Variables entered on step 1: gender (male $1 /$ female 0 ), smoking (smokers $1 /$ non-smokers 0 ), age ( $>35$ years $1 /$ $\leq 35$ years 0 ), $\mathrm{PD}$ and $\mathrm{CAL}(>4 \mathrm{~mm} 1 / \leq 4 \mathrm{~mm} 0$ ), supragingival biofilm and BOP ( $>30 \%$ of sites $1 / \leq 30 \%$ of sites 0 ), $P$. aeruginosa and Acinetobacter spp. (positive $1 /$ negative 0 ).

biofilms may result in the persistence of these pathogens in the periodontal pocket after therapy (Pihl et al., 2010; Smith et al., 2003; Woods et al., 1982). Associations between the presence of $P$. aeruginosa and Acinetobacter spp. and demographic and periodontal clinical parameters were also examined. Both species were detected in significantly higher frequencies in subjects with larger proportions of visible supragingival biofilm, BOP, PD and CAL, reinforcing the relationship of these pathogens with inflammation, tissue destruction and poor oral hygiene (Abe et al., 2001; Colombo et al., 2002, 2009; Da Silva-Boghossian et al., 2011; Paju and Scannapieco, 2007; Scannapieco et al., 1998; Souto and Colombo, 2008; Souto et al., 2006). Indeed, these microorganisms produce virulence factors of relevance to the pathogenesis of periodontitis. $P$. aeruginosa is tissue invasive, elaborates extracellular leukotoxins, suppresses lymphocyte proliferation, inactivate complement components, degrades basement membrane laminin and releases potent enterotoxins and endotoxins (Pihl et al., 2010; Smith et al., 2003; Woods et al., 1982). Acinetobacter spp. are considered major nosocomial pathogens (Bergogne-Berezin et al., 1996) accounting for about $80 \%$ of reported infections. Members of the genus seem to have a remarkable ability to develop resistance to even the most potent antimicrobial agents (Towner, 1997). Obana (1986) demonstrated that some clinical isolates had slime-producing ability, and that the slime also enhanced the virulence of other species, indicating the potential role of Acinetobacter in the enhancement of virulence in mixed infections.

In structured communities, coaggregation of different bacterial species seems to have evolved as an efficient strategy to optimize local opportunities. Studies have indicated that species of Acinetobacter and Pseudomonas, when inserted in highly organized mixed communities, may cooperatively interact with each other, exhibiting direct metabolic communications and frequent genetic exchanges of multi-drug-resistant genes due to the close evolutionary 
proximity (Fournier et al., 2006; Hansen et al., 2007). We found that over $70 \%$ of sites colonized by $P$. aeruginosa were colonized by Acinetobacter spp. In a previous study with hospitalized individuals, our group also demonstrated a strong association between the oral colonization of these microorganisms (Zuanazzi et al., 2010). Furthermore, $P$. aeruginosa and Acinetobacter spp. may interact with other species such as periodontal pathogens. Da Silva-Boghossian et al. (2011) demonstrated that Aggregatibacter actinomycetemcomitans, A. baumannii and the red complex (Porphyromonas gingivalis, Tannerella forsythia, Treponema denticola) associated with $P$. aeruginosa in the subgingival microbiota increased significantly the likelihood of a subject having aggressive periodontitis. $P$. aeruginosa also seemed to have a synergism with $A$. actinomycetemcomitans increasing the risk for periodontal disease. Likewise, Persson et al. (2008) showed that $P$. aeruginosa along with $T$. forsythia were independent predictors for periodontal disease. However, the exact mechanisms involved in these complex interactions are not elucidated yet.

In summary, our findings provide additional evidence for the oral cavity as a reservoir for $P$. aeruginosa and Acinetobacter spp., as well as of the association of these microorganisms with the presence of periodontal infection. Considering that eradication of this species from subgingival biofilm in deep periodontal pockets may be limited, close attention should be given to these patients in order to reduce the risk for periodontal breakdown and/or development of systemic diseases caused by these species in other areas of the body.

\section{Acknowledgments}

This work was supported in part by National Council for Scientific and Technological Development (CNPq), Coordination of Improvement of Higher Education Personnel (CAPES), and Foundation for Research Support of the State of Rio de Janeiro (FAPERJ), Brazil.

\section{References}

Abe S, Ishihara K, Okuda K (2001) Prevalence of potential respiratory pathogens in the mouths of elderly patients and effects of professional oral care. Arch Gerontol Geriatr 32: 45-55.

Agodi A, Barchitta M, Cipresso R, Giaquinta L, Romeo MA, Denaro C (2007) Pseudomonas aeruginosa carriage, colonization, and infection in ICU patients. Intensive Care Med 33:1155-1161.

Ali RWC, Bakken V, Nilsen R, Skaug, N (1994) Comparative detection frequency of 6 putative periodontal pathogens in $\mathrm{Su}-$ danese and Norwegian adult periodontitis patients. J Periodontol 65:1046-1052.

Ali RWC, Velcescu MC, Jivanescu B, Lophtus B, Skaug N (1996) Prevalence of 6 putative periodontal pathogens in subgingival plaque samples from Romanian adult periodontitis patients. J Clin Periodonto. 18:411-415.
Barbosa FC, Mayer MP, Saba-Chujfi E, Cai S (2001) Subgingival occurrence and antimicrobial susceptibility of enteric rods and pseudomonads from Brazilian periodontitis patients. Oral Microbiol Immunol 16:306-310.

Bergogne-Berezin E, Towner KJ (1996) Acinetobacter spp. as nosocomial pathogens: Microbiological, clinical, and epidemiological features. Clin Microbiol Rev 9:148-165.

Botero JE, Contreras A, Lafaurie G, Jaramillo A, Betancourt M, Arce RM (2007) Occurrence of periodontopathic and superinfecting bacteria in chronic and aggressive periodontitis subjects in a Colombian population. J Periodontol 78:696-704.

Broderick NA, Raffa, KF, Goodman RM, Handelsman J (2004) Census of the bacterial community of the gypsy moth larval midgut by using culturing and culture-independent methods. Appl Environ Microbiol 70:293-300.

Chastre J, Fagon J (2002) Ventilator-associated pneumonia. Am J Respir Crit Care Med 165:867-903.

Colombo AP, Boches SK, Cotton SL, Goodson JM, Kent R, Haffajee AD et al. (2009) Comparisons of subgingival microbial profiles of refractory periodontitis, severe periodontitis, and periodontal health using the human oral microbe identification microarray. J Periodontol 80:1421-1432.

Colombo AP, Haffajee AD, Dewhirst FE, Paster BJ, Smith CM, Cugini M A et al. (1998) Clinical and microbiological features of refractory periodontitis subjects. J Clin Periodontol 25:169-180

Colombo AP, Teles RP, Torres MC, Souto R, Rosalem WJ, Mendes MC et al. (2002) Subgingival microbiota of Brazilian subjects with untreated chronic periodontitis. J Periodontol 73:360-369.

Da Silva-Boghossian CM, Souto R, Luiz RR, Colombo APV (2011) Association of red complex, $A$. actinomycetemcomitans and non-oral bacteria with periodontal diaseases. Arch Oral Biol 56:899-906.

De Vos D, Lim JrA, Pirnay JP, Struelens M, Vandenvelde C, Duinslaeger L et al. (1997) Direct detection and identification of Pseudomonas aeruginosa in clinical samples such as skin biopsy specimens and expectorations by multiplex PCR based on two outer membrane lipoprotein genes, oprI and oprL. J Clin Microbiol 35:1295-1299.

Fourrier F, Duvivier B, Boutigny H, Roussel-Delvallez M, Chopin C (1998) Colonization of dental plaque: A source of nosocomial infections in intensive care unit patients. Crit Care Me. 26:301-308.

Fournier PE, Vallenet D, Barbe V, Audic S, Ogata H, Poirel L et al. (2006) Comparative genomics of multidrug resistance in Acinetobacter baumannii. PLoS Genet. 10:2-7.

Fritschi BZ, Albert-Kiszely A, Persson GR (2008) Staphylococcus aureus and other bacteria in untreated periodontitis. J Dent Re. 87:589-593.

Hansen SK, Haagensen JA, Gjermansen M, Jorgensen T. M, Tolker-Nielsen T, Molin S (2007) Characterization of a Pseudomonas putida rough variant evolved in a mixedspecies biofilm with Acinetobacter sp. strain C6. J Bacteriol 189:4932-4493.

Goncalves LdeS, Souto R, Colombo AP (2009) Detection of Helicobacter pylori, Enterococcus faecalis, and Pseudomonas aeruginosa in the subgingival biofilm of HIV-infected 
subjects undergoing HAART with chronic periodontitis. Eur J Clin Microbiol Infect Dis 28:1335-1342.

Karlowsky JA, Draghi DC, Jones ME, Thornsberry C, Friedland IR, Sahm D. F (2003) Surveillance for antimicrobial susceptibility among clinical isolates of Pseudomonas aeruginosa and Acinetobacter baumannii from hospitalized patients in the United States, 1998 to 2001. Antimicrob Agents Chemother 47:1681-1688.

Laine MJ, Farre MA, Crusius BA, Pena S (2000) The mouthwash: A non- invasive sampling method to study cytokine gene polymorphisms. J. Periodontol 71:1315-1318.

Luna CM, Aruj PK (2007) Nosocomial Acinetobacter pneumonia. Respirology 12:787-791.

Obana Y (1986) Pathogenic significance of Acinetobacter calcoaceticus: Analysis of experimental infection in mice. Microbiol Immunol 30:645-657.

Page RC, Kornman, KS (1997) The pathogenesis of human periodontitis: An introduction. Periodontol 2000 14:9-11.

Paju P. Scannapieco FA (2007) Oral biofilms, periodontitis, and pulmonary infections. Oral Diseases 13:508-512.

Paster BJ, Olsen I, Aas JA, Dewhirst FE (2006) The breadth of bacterial diversity in the human periodontal pocket and other oral sites. Periodontol 2000 42:80-87.

Persson GR, Hitti J, Paul K, Hirschi R, Weibel M, Rothen M et al. (2008) Tannerella forsythia and Pseudomonas aeruginosa in subgingival bacterial samples from parous women. J Periodontol 79:508-516.

Pihl MLEC, Schimidtchen A, Svensater G, Davies JR (2010) Effects of clinical isolates of Pseudomonas aeruginosa on Staphylococcus epidermidis biofilm formation. FEMS Immunol Med Microbiol 59:504-512.

Scannapieco FA (1998) Position paper of The American Academy of Periodontology: Periodontal disease as a potential risk factor for systemic diseases. J Periodontol 69:841-850.

Scannapieco FA, Papandonatos GD, Dunford RG (1998) Associations between oral conditions and respiratory disease in a national sample survey population. Ann. Periodontol 3:251-256.

Slots J, Feik D, Rams TE (1990) Prevalence and antimicrobial susceptibility of Enterobacteriacea, Psedomonadaceaea and Acinetobacter in human periodontitis. Oral Microbiol Immunol 5:149-154.
Slots J, Rams TE, Litsgarten MA (1988) Yeasts, enteric rods and pseudomonads in the subgingival flora of severe adult periodontitis. Oral Microb Immunol 3:47-52.

Slots J, Rams TE, Feik D, Taveras HD, Gillespie GM (1991) Subgingival microflora of advanced periodontitis in the Dominican Republic. Oral Microbiol Immunol 62:543-547.

Smith RS, Iglewski BH (2003) P. aeruginosa quorum-sensing systems and virulence. Curr Opin Microbiol 6:56-60.

Socransky SS, Haffajee AD, Cugini MA, Smith C, Kent JrRL (1998) Microbial complexes in subgingival plaque. J Clin Periodontol 25:134-144.

Souto R, Colombo AP (2008) Detection of Helicobacter pylori by polymerase chain reaction in the subgingival biofilm and saliva of non-dyspeptic periodontal patients. J Periodontol 79:97-103.

Souto R, de Andrade AFB, Uzeda M, Colombo APV (2006) Prevalence of "non-oral" pathogenic bacteria in subgingival biofilm of subjects with chronic periodontitis. Braz J Microbiol 37:208-215.

Towner KJ (1997) Clinical importance and antibiotic resistance of Acinetobacter spp. J Med Microbiol 46:721-746.

Vanbroekhoven K, Ryngaert AK, Wattiau P, Mot R, Springael D (2004) Acinetobacter diversity in environmental samples assessed by $16 \mathrm{~S}$ rRNA gene PCR-DGGE fingerprinting. FEMS Microbiol Ecol 50:37-50.

Wagner VE, Iglewski BH (2008) P. aeruginosa biofilms in CF infection. Clin. Rev Allerg Immul 35:124-134.

Willis SG, Smith KS, Dunn VL, Gapter LA, Riviere KH, Riviere GR (1999) Identification of seven Treponema species in health- and disease-associated dental plaque by nested PCR. J Clin Microbiol 37:867-869.

Woods DE, Cryz SJ, Friedman RL, Iglewski BH (1982) Contribution of toxin A and elastase to virulence of Pseudomonas aeruginosa in chronic lung infections of rats. Infect Immun 36:1223-1228.

Zuanazzi D, Souto R, Mattos MB, Zuanazzi MR, Tura BR, Sansone C, Colombo AP (2010) Prevalence of potential bacterial respiratory pathogens in the oral cavity of hospitalised individuals. Arch Oral Biol 55:21-28.

All the content of the journal, except where otherwise noted, is licensed under a Creative Commons License CC BY-NC. 